\title{
Serum osteocalcin levels in girls with central precocious puberty
}

\author{
Young Jun Rhie*, Hyo Kyoung Nam, Kee Hyoung Lee \\ From 7th APPES Biennial Scientific Meeting \\ Nusa Dua, Bali. 14-17 November 2012
}

\section{Objectives}

Bone plays metabolic roles through osteocalcin $(\mathrm{OC})$ when it is released into the systemic circulation in uncarboxylated form. Identified novel metabolic roles of OC include increasing insulin secretion and sensitivity, energy expenditure, reduction of fat mass and mitochondrial proliferation and functional enhancement. The onset of puberty can be influenced metabolic factors. This study was aimed to determine serum OC levels in girls with central precocious puberty(CPP) and to investigate the effects of $\mathrm{OC}$ on the onset of puberty.

\section{Methods}

Serum OC levels of girls CPP $(n=30)$ and their agematched controls $(n=30)$ were measured. GnRH stimulation test was performed in CPP group. Bone age was determined in all subjects.

\section{Results}

Serum OC levels were significantly higher in CPP group compared with control group $(76.8 \pm 10.5$ vs. $61.6 \pm$ $15.1 \mathrm{ng} / \mathrm{mL}, \mathrm{p}=0.001)$. Serum OC levels were correlated with peak $\mathrm{LH}$ levels during $\mathrm{GnRH}$ stimulation test $(\mathrm{r}=0.348, \mathrm{p}=0.037)$, bone age $(\mathrm{r}=0.403, \mathrm{p}=0.010)$ and bone age advance $(\mathrm{r}=0.323, \mathrm{p}=0.042)$, but not related to age, height, weight and BMI.

\section{Conclusions}

Serum OC seems to be associated with the onset of puberty leaving casual relations unresolved.

Submit your next manuscript to BioMed Central and take full advantage of:

- Convenient online submission

- Thorough peer review

- No space constraints or color figure charges

- Immediate publication on acceptance

- Inclusion in PubMed, CAS, Scopus and Google Scholar

- Research which is freely available for redistribution
() Biomed Central

\section{Biomed Central}

